\title{
Effect of transglutaminase addition to chemical, physical, and culture survivability of yogurt during storage period
}

\author{
Setiadi ${ }^{1, *}$, and Jihan Putra Ramdhani ${ }^{1}$ \\ ${ }^{1}$ Department of Chemical Engineering, Faculty of Engineering, Universitas Indonesia, Kampus Baru UI, Depok 16424, West Jawa, \\ Indonesia
}

\begin{abstract}
One way to improve the physical and sensory properties of low fat or nonfat yogurt is by adding a small amount of transglutaminase enzyme into yogurt. Transglutaminase is an enzyme that can cause crosslinking in proteins and is particularly suited for improving the functional properties of food proteins. This study was conducted in order to evaluate the effect of transglutaminase (TGase) addition on some properties of yogurt such as fermentation time, $\mathrm{pH}$, total of lactic acid bacteria, syneresis, viscosity, and microstructure. The enzyme was added at different production steps, those are before addition of starter culture and simultaneously with starter culture addition. Another variations are the concentration of the enzyme $(0.5 ; 1.0$; and 2 grams enzyme/gram milk protein) and the storage period $(1,8$, and 15 days of storage period). It was shown that there were no significant effect of transglutaminase addition to fermentation time. Acid development rate as well as syneresis percentage were reduced with increasing TGase doses meanwhile the viscosity was increased. TGase addition was also shown affecting the total lactic acid bacteria. Based on the electron microscope results, due to the formation of cross-links protein, enzyme addition caused proteins to be distributed more evenly in gel network.
\end{abstract}

\section{Introduction}

Nowadays, health concerns regarding overweight and obesity are increasing, much higher than few decades ago, which leading to some chronic diseases such as hypertension, diabetes, and arthritis [1]. It has been known that balancing dietary intake can help reducing those risks. The easy way to do this is by replacing high calorie foods with low calorie foods and beverages but high in major nutritions that the body needs, such as yogurt.

The development in food processing industry throughtout decades has been leading to the increasing demand of yogurt product by consumers. Manufacturing yogurt traditionally is often causing the physical characteristic such as textrural properties of yogurt limited, while texture is one of the main consideration whether the consumers want to buy the product or not. Another problem that is often to be found in yogurt making is syneresis, a whey separation phenomena that can be seen by the formation of whey layer on top of the yogurt. These problems can be solved by adding solid content so that the total solid content of the milk is increasing, usually by using stabilizer such as pectin or gelatin [2]. In other hand, texture improvement using stabilizer is still controversial and not allowed in many countries [1]. It has been shown that textural properties can be improved by other methods. One way to do this is by adding a low concentration of transglutaminase enzyme to yoghurt manufacturing process.
Transglutaminase is a transferase that can led to cross-links formation in proteins [3]. This enzyme catalyses an acyl transfer reaction between $\gamma$ carboxyamide groups of peptide-bound residues (acyl donor) and the primary amino groups glutamine and lysine residues [4]. This enzimatic protein structural modification is very suitable to improve the functional properties of food. One of the product that can be structurally improved by transglutaminase is yogurt. Yogurt contains casein as its main protein. The caseins are good substrate due to their open structure, while whey proteins, due to its globular structure, have lower tendency to form cross link reaction by transglutaminase $[3,4]$.

The main objectives of this study were to investigate the effect of transglutaminase addition to improve the properties of yogurt. Transglutaminase concentration, stage of transglutaminase addition in the manufacturing process, and storage period will be varied. In order to analyze the effect of transglutaminase on final product, fermentation time, $\mathrm{pH}$, total of lactic acid bacteria, syneresis, viscosity, and microstructural properties were determined.

\section{Materials and methods}

\subsection{Materials}

Fresh milk from local dairy farm with $3.3 \%$ protein content was used in this study. Yogurt starter culture

\footnotetext{
*Corresponding author: setiadi@che.ui.ac.id
} 
contains Lactobacillus bulgaricus, Lactobacillus acidophilus, and Streptococcus thermophilus was purchased from Fermentech Nutri Makmur, a food and beverages fementation technologies based specialist. Microbial transglutaminase used in this study was Activa TG-BW-MH with enzyme activity $61 \mathrm{UE} /$ gram that was a gift from PT Ajinomoto Indonesia.

\subsection{Methods}

The samples were divided to three main category; sample without transglutaminase addition (C), transglutaminase added samples with inactivation process (A), and transglutaminase added samples with adding step simultaneously with culture starter addition (without inactivation process, B). For sample C, fresh milk was pasteurized at $80^{\circ} \mathrm{C}$ for 1 minute, and then cooled down to $43^{\circ} \mathrm{C}$ using a mixture of water and ice. $5 \% \mathrm{v} / \mathrm{v}$ of starter culture was added to the pasteurized milk and then incubated at $43^{\circ} \mathrm{C}$. For samples A, fresh milk was heated to $43^{\circ} \mathrm{C}$. Total 3 batches were made, transglutaminase was added with different concentration: $0.5 ; 1.0 ; 2.0 \mathrm{UE} /$ gram milk protein. This mixture of transglutaminase and milk was then incubated at $43^{\circ} \mathrm{C}$ for 2 hours. After 2 hours of incubation, the mixture was heated to $80^{\circ} \mathrm{C}$ for 1 minute to thermally inactivated the transglutaminase, and then cooled down to $43^{\circ} \mathrm{C}$ using a mixture of water and ice. These samples then were incubated at $43^{\circ} \mathrm{C}$. For samples $\mathrm{B}$, after pasteurization and being cooled down to $43^{\circ} \mathrm{C}$, pasteurized milk was divided into 3 different batches, each was added with transglutaminase concentration: $0.5 ; 1.0 ; 2.0 \mathrm{UE} / \mathrm{gram}$ milk protein respectively. $5 \% \mathrm{v} / \mathrm{v}$ of starter culture and transglutaminase was simultaneously added to the pasteurized milk before the incubation process at $43^{\circ} \mathrm{C}$. The incubation was stopped when the $\mathrm{pH}$ of $\mathrm{C}$ reached 4.3. Samples were then cooled and stored at $4^{\circ} \mathrm{C}$. The tests were conducted each three times, those are after 1 , 8 , and 15 days storage period.

\subsubsection{Analysis of Fermentation Time}

Fermentation time was measured when each sample reached $\mathrm{pH}$ of 4.3 at incubation process. The time needed for each sample to reach 4.3 was recorded then compared to determine the effect of transglutaminase addition to fermentation time.

\subsubsection{Determination of $\mathrm{pH}$}

The $\mathrm{pH}$ was measured in duplicate using a Eutech digital $\mathrm{pH}$-meter by immersing the sensor into the samples. The measurement was done for each sample at 1,8 , and 15 days storage period.

\subsubsection{Determination of Total of Lactic Acid Bacteria}

The determination of total of lactic acid bacteria was done using the procedure stated by The National
Standardization Agency of Indonesia [5]. The dilution of samples was made for $10^{-4}$ to $10^{-7}$ dilution ratio. $1 \mathrm{ml}$ of diluted sample was pipetted to sterile petri dish. Plate count agar (PCA) consisted of $5 \mathrm{~g}$ tryptone, $22.5 \mathrm{~g}$ yeast extract, $1 \mathrm{~g}$ dextrose, $15 \mathrm{~g}$ agar, and 11 distilled water was purchased. $12-15 \mathrm{ml}$ of PCA (added with $1 \%$ of $\mathrm{CaCO}_{3}$ ) at $45^{\circ} \mathrm{C}$ was added to the petri dish. The petri dish was then rotated to mix the mixture in the direction of forward, backward, left, and right. After the mixture became solid agar, the petri dishes were incubated for 48 hours at $35^{\circ} \mathrm{C}$ in upside-down position. Cell counts, performed using Chiltern Colony Counter, were calculated from the colonies formed on agar plates. Total of colonies, expressed in $\mathrm{CFU} / \mathrm{ml}$, were determined using the following equation:

$$
N=\frac{\sum C}{\left[\left(1 x n_{1}\right)+\left(0,1 x n_{2}\right)_{\ldots 1}\right] x d}
$$

with:

$\mathrm{N}$ is total colonies of the sample, expressed in $\mathrm{CFU} / \mathrm{ml}$ $\Sigma C$ is total of colonies for all the calculated petri dish $\mathrm{n}_{1}$ is total of petri dish of first dilution ratio that was calculated

$\mathrm{n}_{2}$ is total of petri dish of second dilution ratio that was calculated

$\mathrm{d}$ is the first dilution ratio

\subsubsection{Syneresis Measurement}

Syneresis measurement was done by using the centrifugation process. Approximately $100 \mathrm{~g}$ sample was prepared in centrifuge cups and then was centrifuged at $3500 \mathrm{rpm}$ for 15 minutes. The clear supernatant was collected, weighed, and syneresis was calculated according to the following equation:

Syneresis $(\%)=\frac{\text { weight of supernatant }(\mathrm{g})}{\text { weight of yogurt sample }(\mathrm{g})} \times 100 \%$

\subsubsection{Determination of Viscosity}

Viscosity of all samples was determined using a DV-1 Prime Brookefield Viscometer (Brookefield Engineering Laboratories, Inc, Massachusetts, USA). The spindle was immersed into the samples, and then the measurement was recorded after the reading stabilized. Measurement was done at speed of 0.3 RPM. The viscosity was expressed in centipoise $(\mathrm{cP})$.

\subsubsection{Microstructural Analysis}

Microstructural analysis was done for $\mathrm{C}$, and A \& B both at concentration $1 \mathrm{UE} / \mathrm{g}$ milk protein, all samples were analyzed for every storage period using SEM (Scanning Electron Microscope). Samples were prepared using procedure stated by Goldstein et al. (1992) [6]. Samples were centrifuged, and then the supernatant was separated from the samples. Glutaraldehyde $2 \%$ was added to the samples and then the mixtures were set for few hours. The samples then were centrifuged and the supernatant

$\overline{{ }^{*} \text { Corresponding author: setiadi@che.ui.ac.id }}$ 
was separated from the samples before tannin acid $2 \%$ was added to the samples. The samples were set for few hours. The samples were then centrifuged, separated from the fixative solution, and then added with caccodylate buffer. The buffer was separated after 10 minutes from the samples using centrifugation, added with caccodylate buffer again, set for 10 minutes, and back to centrifugation process to separate the buffer from the samples. The samples were added with Osmium tetroxide $1 \%$ and set for 1 hour. Centrifugation was conducted once more to separate the solution from the samples. Alcohol 50\% was added, set for 10 minutes, then separated from the samples. Once more, alcohol $50 \%$ was added, set for 10 minutes and then separated from the samples. Alcohol 70\%, alcohol 80\%, and alcohol $95 \%$ were added to the samples and the samples were set for 10 minutes. Centrifugation was conducted to separate samples from alcohol. After centrifugation, samples were added with absolute alcohol, set for 10 minutes and then centrifuged to separate the absolute alcohol (this step was conducted twice). The mixture was added with t-buthanol, set for 10 minutes, then samples were weparated from t-buthanol by centrifugation (conducted twice). Samples were then added with buthanol, and then suspension on buthanol was made. For each sample, cover slip was freezed, a spread of suspension was made on the cover slip and then dried. All the procedure was conducted at $4{ }^{\circ} \mathrm{C}$. After the preparation was done, prepared samples were examined using JSM-5310LV scanning microscope (Jeol Ltd, Tokyo, Japan) operated at $15 \mathrm{kV}$. Micrograph was taken at x 7500 magnification.

\section{Results and discussion}

\subsection{Influence of transglutaminase addition to fermentation time}

Incubation of the samples was stopped after the samples reached $\mathrm{pH}$ of 4.3 . The following table shows the time needed for the samples to reach the $\mathrm{pH}$ of 4.3 .

Table 1. Time needed for the samples to reach the $\mathrm{pH}$ of 4.3

\begin{tabular}{|c|c|c|}
\hline $\begin{array}{c}\text { Enzyme } \\
\text { concentration } \\
\text { (UE/g milk } \\
\text { protein) }\end{array}$ & $\begin{array}{r}\text { Time needed for the samples to reach } \\
\text { the } \mathrm{pH} \text { of } 4.3 \text { (minute) }\end{array}$ \\
\hline 0 (control, C) & \multicolumn{2}{|c|}{259} \\
\hline & Samples A & Samples B \\
\hline 0,5 & 267 & 271 \\
\hline 1 & 272 & 278 \\
\hline 2 & 286 & 288 \\
\hline
\end{tabular}

From the data, it can be concluded that the fermentation time is slightly different for each sample. Sample C took the shortest time to reach the $\mathrm{pH}$ of 4.3, that was approximately 259 minutes. Transglutaminase interferes the growth of the lactic acid bacteria, causing a longer fermentation [1, 7]. From each transglutaminase concentration added to the sample, slight difference was shown, where samples B needed longer fermentation time than Samples A. Without inactivation, the activity of transglutaminase was not stopped, causing both transglutaminase and yogurt culture worked at the same time, where it has been stated before that transglutaminase can cause delay in growth of lactic acid bacteria. As the concentration of transglutaminase was increased, the fermentation time became slightly longer. It makes sense since the addition of small amount of transglutaminase can lead to longer fermentation time, so the more transglutaminase added to the samples, the more time they needed to reach the desirable $\mathrm{pH}$. Nevertheless, the difference of fermentation time among the samples is not significant. This result is in agreement with previous studies $[1,3,4,7,8]$.

\subsection{Influence of transglutaminase addition to $\mathrm{pH}$}

Lactic acid formed from activity of lactic acid bacteria lead to increasing acidity and decreasing $\mathrm{pH}$. From this study, it was shown that $\mathrm{pH}$ of the samples were decreasing as the storage period getting longer (Fig. 1).

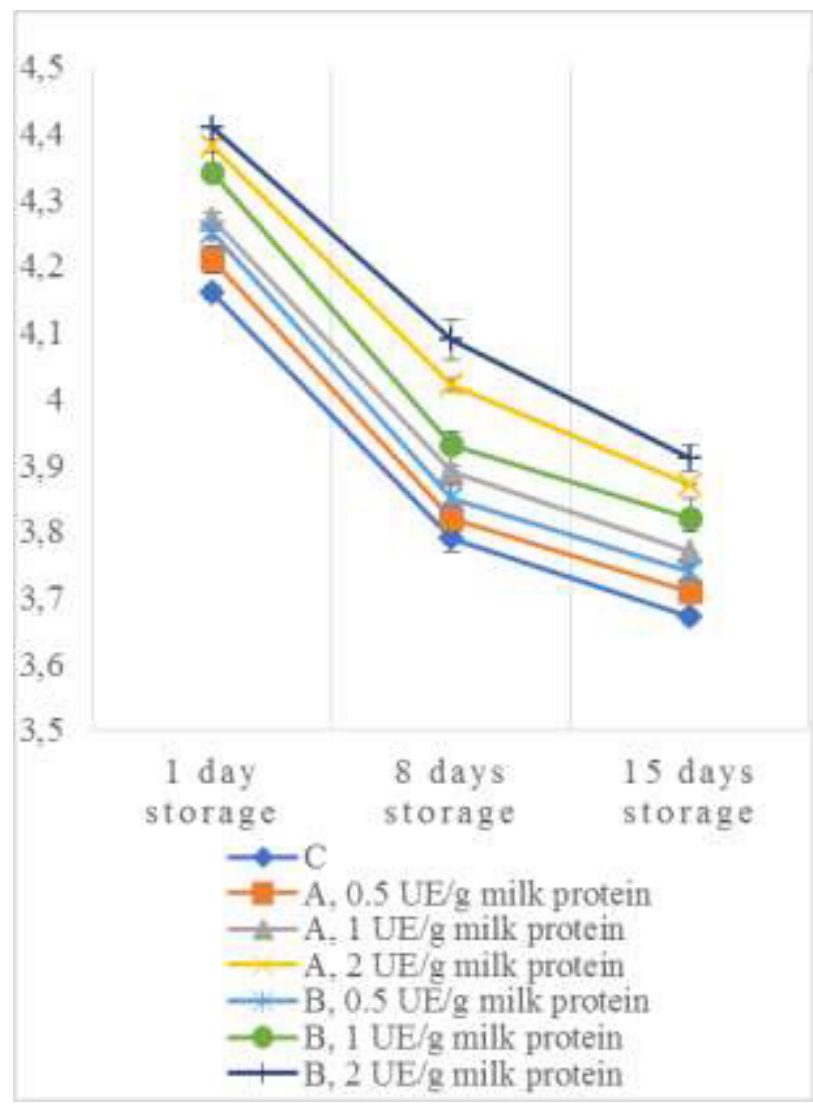

Fig. 1. Variation of $\mathrm{pH}$ of each sample during storage period at $4^{\circ} \mathrm{C}$

During storage period, $\mathrm{pH}$ was decreasing because lactic acid bacteria can produce lactic acid even during the storage period [9]. This study also shows that

\footnotetext{
*Corresponding author: setiadi@che.ui.ac.id
} 
transglutaminase addition was holding up the acidity development during the storage period, in agreement with Aprodu et al. (2012) and Ozer et al. (2007) [1, 4]. As stated before, transglutaminase can cause delay in growth of lactic acid bacteria in yogurt. The higher concentration of transglutaminase added, acidity development became slower. This result is in agreement with Ozer et al (2007) [4]. Domagala et al. (2013) [10], had also found similar result when varied the transglutaminase concentration and storage period to goat milk yogurt.

From this study, it was shown that samples B had slower acidity development compared to samples A. This was caused by the fact that during the storage period, the enzyme was still active for samples B due to no inactivation process conducted, leading to slower acidity development. This result is in agreement with Neve et al (2001) [7] that stated that the growth rate of Streptococcus thermophilus and Lactobacillus bulgaricus was found slower for samples without inactivation in the manufacturing process.

\subsection{Influence of transglutaminase addition to total of lactic acid bacteria}

From Fig. 2, it can be concluded that transglutaminase addition led to slower growth of lactic acid bacteria in yogurt. Sample control had higher viability of lactic acid bacteria than samples with transglutaminase addition. This result is in agreement with previous studies [2, 4, 7]. Lactic acid bacteria used in this study were Lactobacillu bulgaricus, Lactobacillus acidophilus, and Streptococcuc thermophilus. According to Neve et al. (2001) and Ozer et al. (2007) [4, 7], total of Lactobacillus bulgaricus tends to be stable on sample control as well as sample with transglutaminase addition. Fransworth et al. (2006) [2] reported that there were no significant change in the population of Lactobacillus adidophilus when transglutaminase treatment was applied to the manufacturing of goat milk yogurt. Based on these reports, decrease in viability count of lactic acid bacteria was caused by the effect of transglutaminase activity to Streptococcus thermophilus viability, as reported in Ozer et al. (2007) and Neve et al. (2001) [4, 7].

Lactobacillus bulgaricus, Lactobacillus acidophilus, and Streptococcus thermophilus benefit each other growth in yogurt. One strain provides compound that is promoting the growth of other strain. According to Ghandi and Shah (2014) [11], Lactobacillus bulgaricus has active proteolytic system, as well as Lactobacillus acidophilus. Proteolytic bacteria is kind of bacteria that produce extracellular protease that can hydrolyze peptide bonds in proteins and then releases it out of the cell. On the other hand, Streptococcus thermophilus does not express or express in a very low level of cell wall proteinase. Amino acids resulted from proteolytic system of Lactobacillus bulgaricus and Lactobacillus acidophilus are the main promoting growth compound for Streptococcus thermophilus. In return, Streptococcus thermophilus provides other growth stimulating factor for lactobacilli, such as formic acid and $\mathrm{CO}_{2}$ [7].

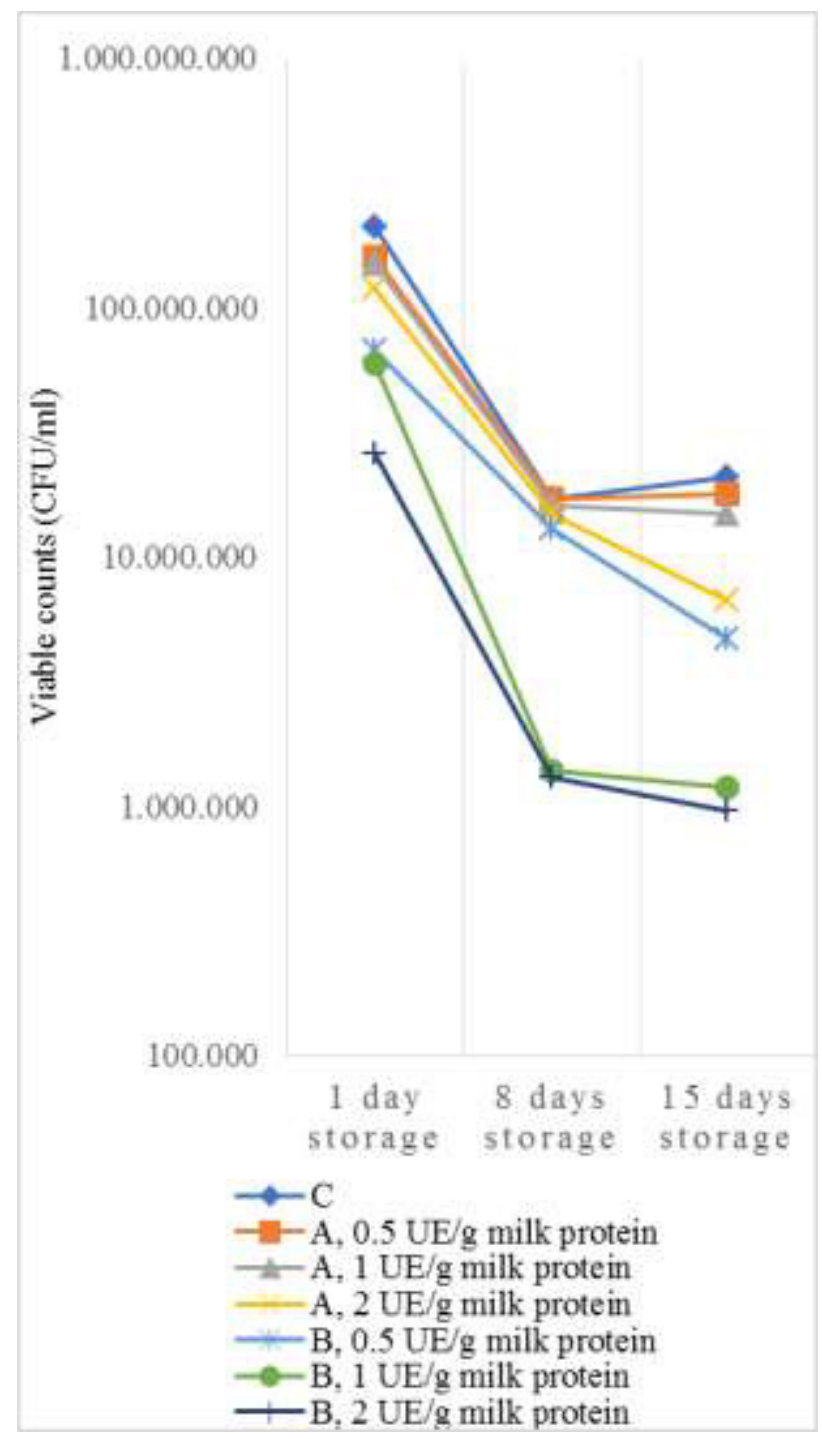

Fig. 2. Viable counts of lactic acid bacteria of each sample during storage period at $4^{\circ} \mathrm{C}$

The serious delay in lactic acid bacteria growth rate in this study probably was happened because amino acids and/or peptide with low molecular weight that were needed for Streptococcus thermophilus to grow were cross-linked by transglutaminase activity, resulted in there were not much left of amino acids and/or peptide that can be used by Streptococcus thermophilus. Since Lactobacillus bulgaricus, Lactobacillus acidophilus, and Streptococcus thermophilus support each other's growth, the delay in one strain growth can affect other's growth as well. Hence, the total of lactic acid bacteria in this study was decreasing. This result is in agreement with previous studies $[4,7]$.

Compared to samples A, samples B had lower number of viability of the lactic acid bacteria. The noninactivated transglutaminase in samples B was causing more amino acids and/or peptide to be cross-linked, leading to less amino acids that can be used by Streptococcus thermophilus to grow. The result was also

*Corresponding author: setiadi@che.ui.ac.id 
shown that the higher concentration of transglutaminase added to the sample, the growth of the bacteria was getting slower. This result is in agreement with previous study [4].

\subsection{Influence of transglutaminase addition to syneresis percentage}

Syneresis is a shrinkage gel phenomena, leads to whey separation and can be defined as the appearance of whey on the yogurt surface [2]. Fig. 3 shows the result of this study to syneresis percentage of each sample.

From this result, it can be seen that sample $\mathrm{C}$ has higher percentage of syneresis compared to other samples. Transglutaminase addition has been reported can improve the water holding capacity of the yogurt samples. Casein that is the main protein in milk is a good substrate for transglutaminase [3, 4]. Acidification process on sample with transglutaminase addition results in more solid gel, lower permeability, and stronger protein network [1].

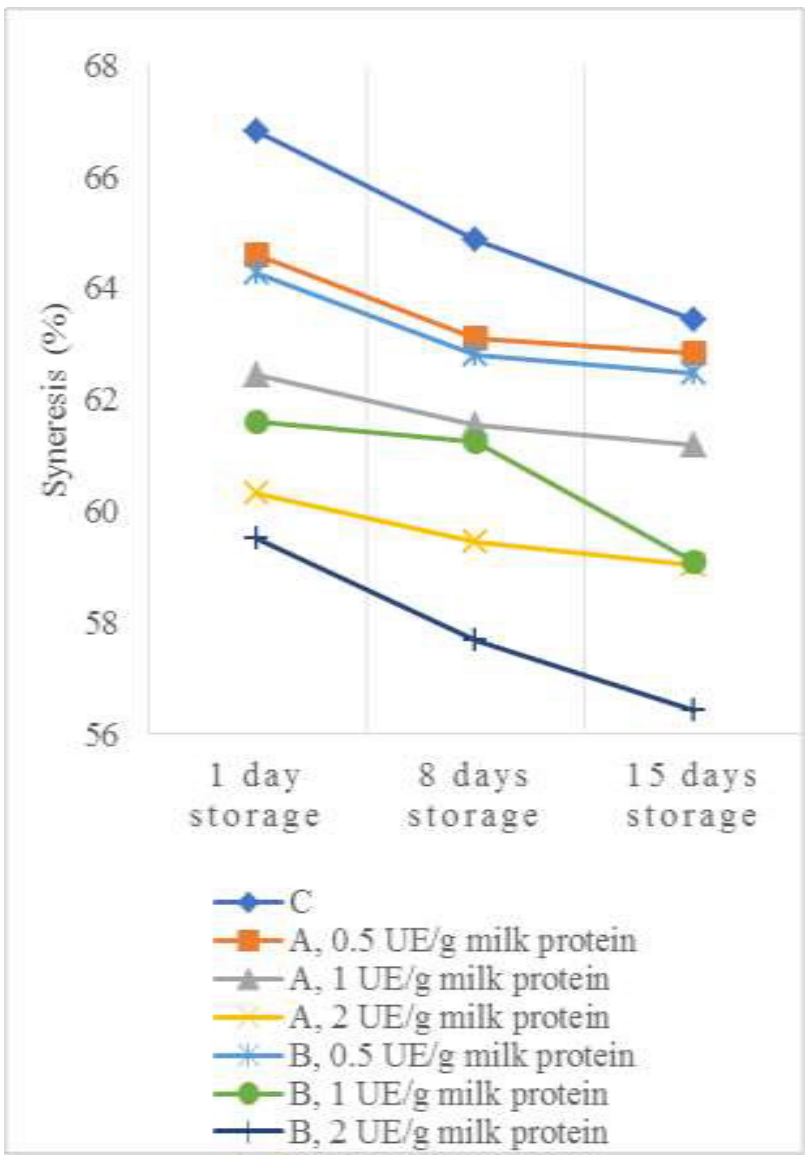

Fig. 3. Changes in syneresis percentage of each sample during storage period at $4^{\circ} \mathrm{C}$

It can be concluded that protein cross-linking is a promising way to stabilize the three dimensional network of yogurt product. The higher concentration of transglutaminase added, the syneresis percentage was more reduced. This result is in agreement with previous studies $[1,2]$. Because gel is formed from cross-link between lysine and glutamine residues, these samples had better water holding capacity than sample control, leading to lower whey separation [2]. On the other hand, decrease in syneresis was possibly caused by the effect of transglutaminase to the size of the gel pore. When the size of the pore is reduced, protein network is formed leading to lower syneresis percentage.

From this study, it can be concluded that transglutaminase was still active during storage period based on the fact that the syneresis of each sample with transglutaminase addition is decreasing throughout the storage period. The result also showed that samples B had lower syneresys percentage than samples A, due to the non-inactivation process at the making of samples B, causing the transglutaminase worked even during the storage period. Generally, syneresis can be avoided by adding solid content or stabilizer to the manufacturing process, but some previous researches have shown that the process can influence the sensory of the final product $[1,2]$.

\subsection{Influence of transglutaminase addition to viscosity of the samples}

Viscosity is probably the main characteristic in comparing the quality of yogurt with and without transglutaminase. Fig. 4 shows the result of the samples' viscosity.

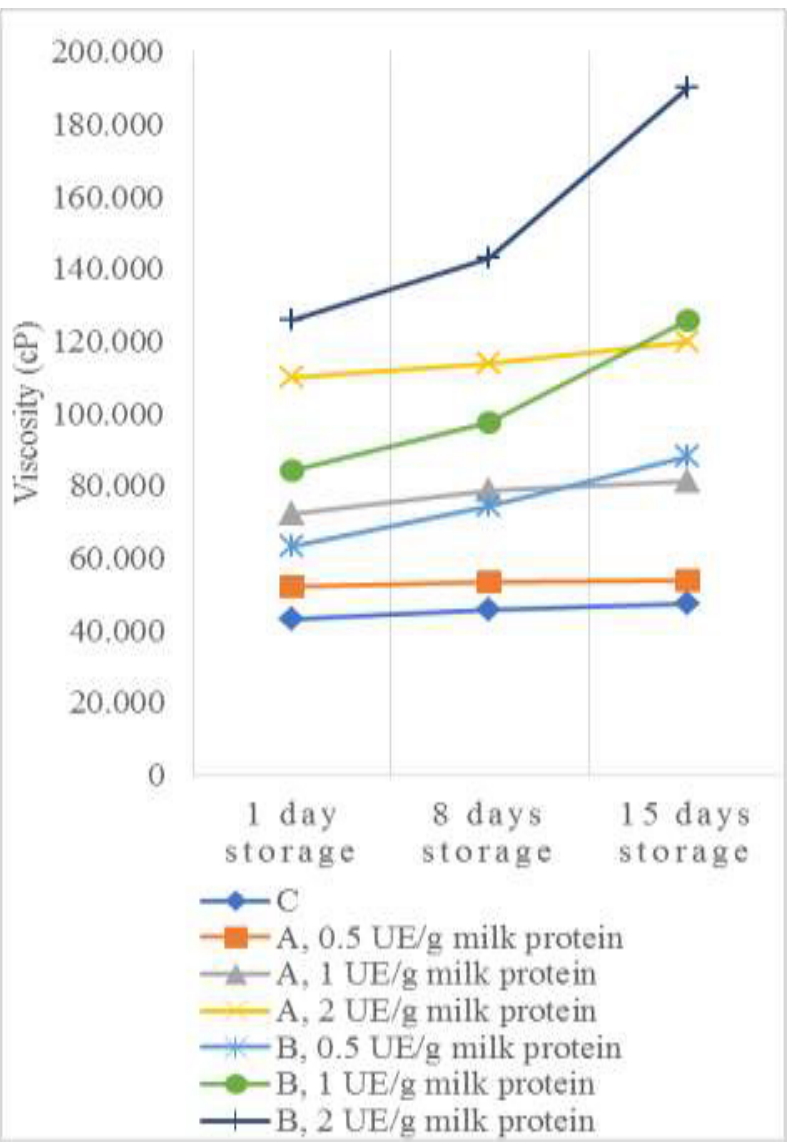

Fig. 4. Changes in viscosity of each sample during storage period at $4^{\circ} \mathrm{C}$

\footnotetext{
*Corresponding author: setiadi@che.ui.ac.id
} 
From Fig. 4, it can be seen that the viscosity of the samples with transglutaminase addition are higher in viscosity than sample control. This result is in agreement with previous studies $[1-4,10]$. The difference of the viscosity was caused by cross-linking reaction between milk proteins that was the result of transglutaminase activity. Samples B showed to have higher viscosity than samples A (because samples B did not go through inactivation process), but both samples A and samples B showed the same trend (increasing) when the concentration of transglutaminase was increased. During the storage period, the viscosity of samples B increase significantly, while samples A showed non-significant development. The graph for samples B are getting steeper as the concentration of transglutaminase is increasing. This result was caused by the fact that transglutaminase is still active even in cold temperature.

\subsection{Influence of transglutaminase addition to microstructural properties during storage period}

It can be seen from Fig. 5 that the protein matrices of the samples with transglutaminase addition appeared to be more compact than sample control. From the micrographs, sample control tended to have smoother surface while the casein surface of sample A and sample B tended to be coarser. Sample control was also shown to have no significant changes in term of protein microstructure during storage period. Different from sample A, sample B had more compact structure. During storage period, sample B also showed to have more compact structure than sample A, eventhough sample that was used in this analysis had the same enzyme concentration, both for sample A and sample B.

This analysis confirmed the results done by previous research $[2,12]$ that stated the higher strength of yogurt gels from cross-linked milk was due to a well organized protein network with smaller pores in the product. Yogurt with transglutaminase addition had more sistemically and smoothly distributed proteins with a bit coarse structure and less porosity in protein network [3]. Transglutaminase activity in yogurt led to a decrease in gel permeability, causing a more compact and stable microstructure [4]. The result of this study is similar with the result of previous research [10] that stated the protein matrix of control yogurt consisted of aggregates casein micelle particles and the sizes remained the same during the storage period, while the structure of the samples with transglutaminase addition were very compacted compared to the sample control. The result of this study is also in agreement with Farnsworth et al. (2006) [2] where the higher concentration of transglutaminase added to yogurt sample, the higher strength of yogurt gels from cross-linked protein is formed. The structure become more compact and finer-meshed network of protein is formed, leading to improved gel strength and lower syneresis percentage. From this study, it was shown that transglutaminase addition without inactivation process led to more compact structure since the enzyme was still active during storage period. Based on the micrographs resulted from this study, it can be concluded that transglutaminase addition can improve the gel strength of yogurt product.

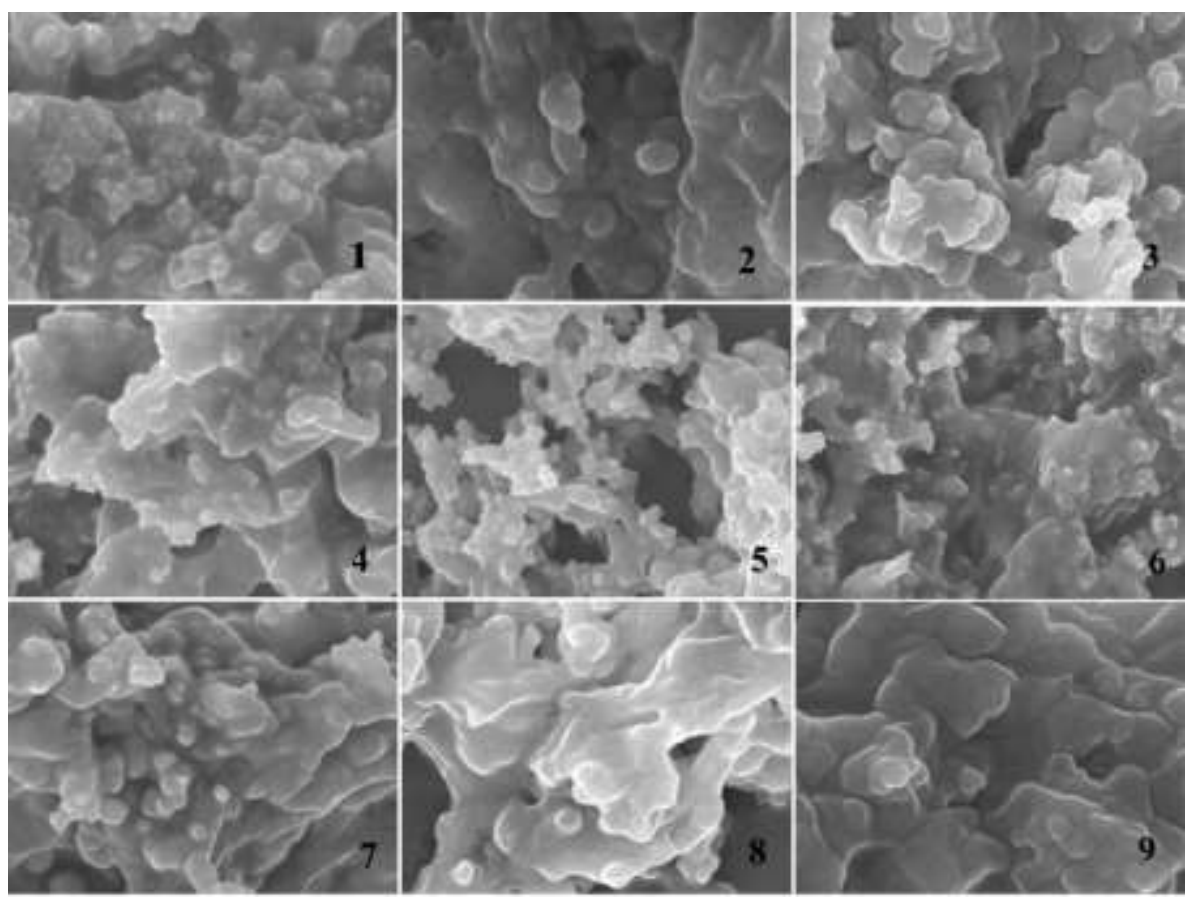

Fig. 5. Scanning electron micrographs at magnification $x 7500$ of yogurt samples after storage period at $4^{\circ} \mathrm{C}:(1),(2)$, and (3) are sample control during 1,8 , and 15 days storage period, respectively; (4), (5), and (6) are samples A with enzyme concentration 1 $\mathrm{UE} / \mathrm{g}$ milk protein during 1,8 , and 15 days storage period, respectively; (7), (8), and (9) are samples B with enzyme concentration 1 $\mathrm{UE} / \mathrm{g}$ milk protein during 1,8 , and 15 days storage period, respectively.

$\overline{{ }^{*} \text { Corresponding author: setiadi@che.ui.ac.id }}$ 


\section{Conclusion}

Transglutaminase was found to be an effective way to improve viscosity and reduce syneresis of yogurt. There was no significant difference showed from this study for fermentation time. The transglutaminase addition led to slower acidity development as well as lactic acid bacteria growth rate. It had also been shown from this study that transglutaminase addition to yogurt product caused a more compact structure of yogurt matrix protein. Based on this study, it was shown that the results were dependent on the level of transglutaminase added to the milk during the manufacturing process, and for sample with transglutaminase adding step simultaneously with culture starter addition it was also dependent on the duration of storage period of the yogurt. According to these results, it can be concluded that transglutaminase can be suggested to improve yogurt properties.

The authors would like to acknowledge the grant "Publikasi Internasional Terindeks untuk Tugas Akhir Mahasiswa" (PITTA) Universitas Indonesia with Grant number 2525/UN2.R3.1/HKP.05.00/ 2018 for the financial support during this research. The authors would also like to thank PT. Ajinomoto Indonesia for providing the transglutaminase enzyme for this study.

\section{References}

1. I. Aprodu, C. E. Masgras, I. Banu, Fascicle VIFood Tech, 36 (2012)

2. J. P. Farnsworth, J. Li, G. M. Hendricks, M. R. Guo, Small Ruminant Res, 65 (2006)

3. T. Şanli, E. Sezgin, O. Deveci, E. Şenel, M. Benli, Food Hydrocolloids, 25 (2011)

4. B. Ozer, H. A. Kirmaci, S. Oztekin, A. Hayaloglu, M. Atamer, Int. Dairy J, 17 (2007)

5. BSN, Cara uji mikrobiologi-Bagian 3: Penentuan angka lempeng total (ALT) pada produk perikanan, SNI 01-2332.3-2006 (2006)

6. J. I. Goldstein, D. E. Newbury, P. Echlin, D. C. Joy, A. D. Romig Jr, C. E. Lyman, C. Fiori, E. Lifshin, Scanning electron microscopy and X-ray microanalysis : A text for biologist, materials Scientist, and cytologists, $2^{\text {nd }} e d, 820$ p. (1992)

7. V. H. Neve, P. C. Lorenzen, A. Mautner, E. Schlimme, K. J. Heller, Kieler Milchwirtschaftliche Forschungsberichte, 53 (2001)

8. M. S. Tsevdou, E. G. Eletheriou, P. S. Taoukis, IFSET, 17 (2013)

9. W. Wang, Y. Bao, G. M. Hendricks, M. Guo, Int. Dairy J, 24 (2012)

10. J. Domagala, M. Wszolek, A. Y. Tamime, B. Kupiec-Teahan, Small Ruminant Res, 112 (2013)

11. A. Gandhi, N. P. Shah, Int. J. Food Sci. Nutr, 65 (2014)

12. H. S. Aloğlu, Z. Öner, Small Ruminant Res, 109 (2013)

\footnotetext{
*Corresponding author: setiadi@,che.ui.ac.id
} 